\title{
Article \\ Bond to Bar Reinforcement of PET-Modified Concrete Containing Natural or Recycled Coarse Aggregates
}

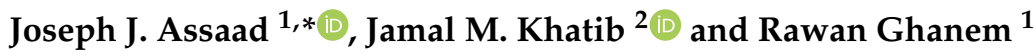 \\ 1 Department of Civil and Environmental Engineering, Faculty of Engineering, University of Balamand, \\ Al Kurah P.O. Box 100, Lebanon; rawan.ghanem@std.balamand.edu.lb \\ 2 Faculty of Engineering, Beirut Arab University, Beirut P.O. Box 115020, Lebanon; j.khatib@bau.edu.lb \\ * Correspondence: joseph.assaad@balamand.edu.lb
}

check for updates

Citation: Assaad, J.J.; Khatib, J.M.; Ghanem, R. Bond to Bar

Reinforcement of PET-Modified

Concrete Containing Natural or

Recycled Coarse Aggregates.

Environments 2022, 9, 8. https:/ /

doi.org/10.3390/environments9010008

Academic Editor: Dimitrios Komilis

Received: 27 November 2021

Accepted: 4 January 2022

Published: 6 January 2022

Publisher's Note: MDPI stays neutral with regard to jurisdictional claims in published maps and institutional affiliations.

Copyright: (C) 2022 by the authors. Licensee MDPI, Basel, Switzerland. This article is an open access article distributed under the terms and conditions of the Creative Commons Attribution (CC BY) license (https:// creativecommons.org/licenses/by/ $4.0 /)$.

\begin{abstract}
The use of post-consumer plastics in concrete production is an ideal alternative to dispose of such wastes while reducing the environmental impacts in terms of pollution and consumption of natural resources and energy. This paper investigates different approaches (i.e., reducing water-to-cement ratio and incorporating steel fibers or polymeric latexes) that compensate for the detrimental effect of waste plastics on the drop in concrete mechanical properties including the bond to embedded steel bars. The polyethylene terephthalate (PET) wastes used in this study were derived from plastic bottles that were shredded into small pieces and added during concrete batching at $1.5 \%$ to $4.5 \%$, by total volume. Test results showed that the concrete properties are degraded with PET additions, given their lightweight nature and poor characteristic strength compared to aggregate particles. The threshold PET volumetric rates are $4.5 \%$ and $3 \%$ for concrete made using natural or recycled aggregates, respectively. The reduction of $\mathrm{w} / \mathrm{c}$ from 0.55 to 0.46 proved efficient to refine the matrix porosity and reinstate the concrete performance. The incorporation of $0.8 \%$ steel fibers (by volume) or $15 \%$ polymers (by mixing water) were appropriate to enhance the bridging phenomena and reduce the propagation of cracks during the pullout loading of steel bars.
\end{abstract}

Keywords: concrete; PET waste; recycled aggregates; SBR polymers; steel fibers; bond strength

\section{Introduction}

Large amounts of waste plastic are generated every year; it is estimated that more than 240 million tons of such wastes were generated in 2016 of which a large part is not recycled [1]. Therefore, any attempt to recycle the waste plastic is beneficial to reduce pollution and burden on the environment including the reduction in $\mathrm{CO}_{2}$ emission. The recent COP26 conference in Glasgow-UK highlighted the need for achieving net-zero emission by 2050 [2].

Numerous studies investigated the possibility of incorporating plastic waste in concrete mixtures, thus contributing to efficient management and sustainable development of the construction industry. Such wastes often derive from polyethylene terephthalate (PET), polypropylene (PP), polyvinyl chloride (PVC), low- or high-density polyethylene (LDPE, HDPE), polylactic acid (PLA), and other resins [3-5]. The wastes are lightweight in nature and are generally shredded into pieces of different gradations to replace part of the fine and/or coarse aggregate fractions. Choi et al. [6] investigated the use of manufactured recycled PET lightweight aggregate as partial replacement of sand on mortar and concrete mechanical properties. The gradual decrease in compressive strength of PET-modified mixtures was mainly attributed to the lower density of PET aggregates; the decrease in strength can reach $30 \%$ when $75 \%$ of aggregate is replaced by recycled PET. Similar conclusions were drawn by Hannawi et al. [7], Khatib et al. [8], and Saxena et al. [9] who studied the use of up to $50 \%$ plastic waste as partial replacement of fine aggregates. Liu et al. [10] compared the performance of incorporating regular and irradiated plastic wastes on concrete properties. While there was a systematic decrease in the compressive and tensile 
strengths with the increase in regular plastic waste content, the use of irradiated wastes enhanced these properties due to microstructure improvement. Saikia and De Britto [11] reported a reduction in compression, splitting tension, flexural strength, and modulus of elasticity of concrete incorporating PET aggregate. The abrasion resistance of concrete with recycled PET was better than the reference concrete, while the flaky PET aggregates were found to bridge the cracks better than concrete made with a natural aggregate only. Belmokaddem et al. [12] attributed the drop in strength of PET-modified mixtures to the weaker interfacial zone between the plastic aggregate and matrix.

The durability of PET-modified concrete is well documented in the literature. Basha et al. [13] studied the effect of replacing the aggregate with different contents, sizes, and shapes of recycled plastic on the properties of concrete and concluded that, with careful mixing proportion, it is possible to produce concrete with 28-day compressive strength of $17 \mathrm{MPa}$ using 100\% recycled plastic. This type of concrete should be suitable for structural applications. Hannawi et al. [7] showed that mixtures incorporating plastic wastes exhibited reduced thermal conductivity together with increased porosity and permeability levels. Ferreira et al. [14] reported that concrete containing high waste plastic volume exhibits better performance when a mixed curing environment (i.e., air and wet) is employed, due to a better bond between the plastic and cement paste. Adamu et al. [15] conducted an experimental study on the effect of plastic waste and graphene nanoparticles on the properties of high-volume fly ash concrete. The incorporation of plastic wastes led to an improvement in workability, whereas the workability was curtailed in the presence of graphene nanoparticles. The mechanical properties (i.e., compressive, splitting, and flexural strengths) and durability (i.e., water absorption) degraded with PET additions, albeit the incorporation of graphene nanoparticles compensated the loss in strength and durability.

The construction industry consumes excessive quantities of virgin materials. Concrete is the dominant material used in construction and aggregate forms the biggest part. In addition to the large amounts needed for construction, natural coarse aggregate (NCA) requires quarrying, processing, and transportation to the construction site. Replacing part of aggregate with recycled materials can offer a distinct advantage, thus reducing the number of raw materials used and plastic waste which is normally destined to landfill [16-18]. This would conserve natural resources and reduce the environmental impact of waste materials.

Several studies investigated the concrete mechanical and structural properties following the partial or complete NCA replacement by recycled concrete aggregate (RCA). In general, it has been observed that the concrete compressive and tensile strengths are reduced with RCA inclusion, given the increased aggregate porosity and reduced density [18,19]. Xie and Zhao [20] examined the effect of RCA on bond strength between steel bars and concrete, with both studies concluding that such additions caused a substantial reduction in strength. The steel-concrete bond strength particularly decreased when the RCA concrete is exposed to salt-frost cycles [21]. Godat et al. [22] studied the bond strength between RCA-modified concrete and glass, carbon, and basalt fiber reinforced plastic bars and concluded that the presence of recycled aggregates enhanced the bearing friction between the bars and concrete. The authors proposed an equation to predict the bond strength and slip behavior of RCA concrete. Wang et al. [23] reported that concrete should not contain more than $70 \%$ RCA to attain an adequate bond between basalt rebars and surrounding concrete.

The incorporation of steel fibers (SR) and bonding agents such as styrene-butadiene rubber (SBR) latexes is common to improve certain concrete mechanical properties, which can be of particular interest for PET-modified mixtures [24-26]. Miranda et al. [27] examined the steel-concrete bond behavior for cylindrical and cubic specimens with and without the inclusion of SF. A $96 \%$ increase in bond stress was observed with the use of $8 \mathrm{~kg} / \mathrm{m}^{3}$ SF. While the bond was independent of the steel diameter, the casting direction of cubic specimens had a direct effect on the ultimate bond strength. Watts et al. [28] concluded that the presence of macro-fibers improved the bond strength including the post-peak behavior, especially at early ages of curing. Raad and Assaad [29] attributed such improvement to a 
fiber bridging effect that reduces the initiation and propagation of cracks, leading to better confinement and bearing capacity around the steel bars. A similar improvement in bond is observed when SBR latexes are incorporated in concrete, which can be attributed to a coalescence of polymers in the cement matrix that reduce the microcrack development during tensile loading [25,30]. Other scholars associated the improved bond due to polymer additions to their hydrophilic nature that reduces bleeding and strengthens the interfacial steel-concrete stresses [30-32]. The use of latexes found wide acceptance in cementitious materials intended for repair, adhesive, and rehabilitation works.

To date, limited studies investigated the bond properties to steel reinforcement of PET-modified concrete mixtures, particularly those containing RCA materials. This paper is part of a comprehensive work undertaken to assess the structural performance of mixtures containing PET additions, mainly the bond to steel bars. Two concrete series prepared with NCA or $100 \%$ RCA replacement are investigated, with PET wastes added between $0 \%$ and $4.5 \%$ by volume. The effect of reducing the free mixing water or incorporating SF or SBR to restore the bond properties is evaluated. The flexural and shear strength properties of reinforced concrete beams containing PET wastes are presented in a followup publication. Such data can be of particular interest to concrete technologists and environmental organizations seeking the use of plastic wastes in concrete intended for structural applications.

\section{Experimental Program}

\subsection{Materials}

Portland cement complying with ASTM C150 Type I was used; its specific gravity and Blaine surface area were 3.15 and $340 \mathrm{~m}^{2} / \mathrm{kg}$, respectively. A naphthalene-based high-range water reducer (HRWR) complying with ASTM C494 Type F was employed [33]; its specific gravity and solid contents were 1.205 and $41.5 \%$, respectively. This admixture can be used up to $4 \%$ of cement mass, with minimum secondary effects such as an increase in air content or excessive delay in setting.

The siliceous sand and crushed limestone natural coarse aggregate (NCA) complied with ASTM C33 [34]. The sand had a water absorption, fineness modulus, and bulk specific gravity of $0.95 \%, 2.36$, and 2.62 , respectively, while the coarse aggregate had a maximum nominal size, water absorption, fineness modulus, and bulk specific gravity of $20 \mathrm{~mm}, 0.8 \%, 6.6$, and 2.72, respectively. The recycled coarse aggregate (RCA) was sourced from a specially produced parent concrete containing $375 \mathrm{~kg} / \mathrm{m}^{3}$ cement, water-to-binder ratio $(\mathrm{w} / \mathrm{b})$ of 0.48 , and the sand-to-total aggregate ratio of 0.55 ; its mean 28 -days $\mathrm{f}^{\prime} \mathrm{c}$ was $42 \pm 4 \mathrm{MPa}$ [19]. The crushing was realized using a laboratory jaw crusher capable of producing particle sizes varying from 0 to $20 \mathrm{~mm}$. The RCA is collected by sieving the crushed concrete through a 4.75-mm sieve to obtain the $4.75 / 20 \mathrm{~mm}$ fraction.

The RCA bulk density, specific gravity, and fineness modulus were $1550 \mathrm{~kg} / \mathrm{m}^{3}, 2.41$, and 6.72, respectively. The materials finer than $75-\mu \mathrm{m}$ and water absorption determined as per ASTM C117 and C128 are $0.78 \%$ and $6.8 \%$, respectively [35,36]. The adhered amount of cement paste was determined by immersing around 100-g RCA in 30\% concentrated $\mathrm{HCl}$ solution for $24 \mathrm{~h}$ (i.e., sufficient to dilute the cement matrix), which then is neutralized by water rinsing through a 75- $\mu \mathrm{m}$ sieve, followed by oven-drying [19]. The attached paste calculated as the difference between the sample mass before and after the acid attack was found to vary within $34 \% \pm 3 \%$.

The PET semi-crystalline polymer materials used in this study are derived from plastic bottles, which were cut using a 3-kW motor power shredding machine. As shown in Figure 1, the shredded pieces had irregular shapes with varying sizes between 1 to $6 \mathrm{~mm}$; these were washed to ensure cleanliness before usage in concrete batching. The PET melting point is $260{ }^{\circ} \mathrm{C}$, while the tensile strength and Young's modulus are $62 \mathrm{MPa}$ and $2.8 \mathrm{GPa}$, respectively. Its specific gravity, density, and water absorption are $1.11 \mathrm{~g} / \mathrm{cm}^{3}, 460 \mathrm{~kg} / \mathrm{m}^{3}$, and $0.01 \%$ (i.e., almost nil), respectively. 


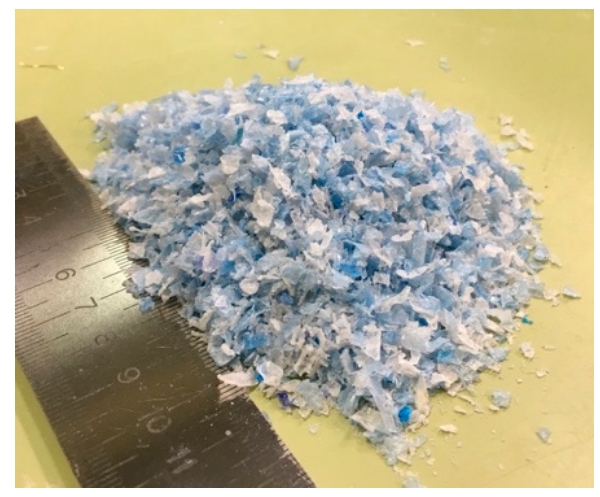

Figure 1. Photo of the shredded PET particles.

Commercially available styrene-butadiene rubber (SBR) commonly used for enhancing adhesion and flexibility of cementitious materials is employed in this study. This carboxylated latex contains $60 \%$ of bound styrene stabilized in water using an anionic emulsifying system. Its solid content, specific gravity, $\mathrm{pH}$, Brookfield viscosity, maximum particle size, and minimum film-forming temperature are $54 \%, 1.04,8.3,235 \mathrm{cP}, 0.22 \mu \mathrm{m}$, and $-5{ }^{\circ} \mathrm{C}$, respectively. The steel fibers (SF) had an aspect ratio of 72 ; these consist of micro-filaments having a length and diameter of 13 and $0.18 \mathrm{~mm}$, respectively. The SF tensile strength hovered about $2600 \pm 200 \mathrm{MPa}$. The concrete bond stress-slip properties to embedded reinforcement were determined using deformed ASTM A615 [37] steel bars having $10 \mathrm{~mm}$ nominal diameter $\left(\mathrm{d}_{\mathrm{b}}\right)$. The bars average yield strength and Young's modulus are $510 \pm 30 \mathrm{MPa}$ and $205 \pm 20 \mathrm{GPa}$, respectively.

\subsection{Concrete Proportions}

The control NCA mixture contained $350 \mathrm{~kg} / \mathrm{m}^{3}$ cement and $0.55 \mathrm{w} / \mathrm{c}$; its average 28-days compressive strength $\left(\mathrm{f}^{\prime} \mathrm{c}\right)$ is $35.43 \mathrm{MPa}$, making it suitable as medium strength grade concrete for commercial and residential applications. The PET particles were incorporated at $1.5 \%, 3 \%$, and $4.5 \%$ rates, by the total concrete volume (i.e., no further additions were used given the dramatic drop in the concrete strength). The fine and coarse aggregate contents were adjusted following the volumetric method to maintain the fixed sand-to-total aggregate ratio of 0.45 (Table 1 ).

Table 1. Typical concrete mix design proportions.

\begin{tabular}{cccccc}
\hline & \multicolumn{3}{c}{ Natural Aggregates } & \multicolumn{2}{c}{ Recycled Aggregates } \\
\hline Cement, $\mathrm{kg} / \mathrm{m}^{3}$ & 350 & 350 & 350 & 350 & 350 \\
Water, $\mathrm{kg} / \mathrm{m}^{3}$ & 193 & 193 & 160 & 193 & 160 \\
$\mathrm{w} / \mathrm{c}$ & 0.55 & 0.55 & 0.46 & 0.55 & 0.46 \\
Fine aggregate, $\mathrm{kg} / \mathrm{m}^{3}$ & 810 & 750 & 800 & 710 & 750 \\
Coarse aggregate, $\mathrm{kg} / \mathrm{m}^{3}$ & 990 & 940 & 980 & 870 & 920 \\
PET, \% by volume & 0 & 4.5 & 4.5 & 4.5 & 4.5 \\
\hline
\end{tabular}

Three approaches (i.e., $\mathrm{w} / \mathrm{c}$ reduction and incorporation of SBR or SF) were considered to mitigate the curtail in the PET-modified concrete properties. Hence, the $\mathrm{w} / \mathrm{c}$ was reduced to 0.46 following preliminary tests, and HRWR dosage was adjusted to maintain a fixed slump of $200 \pm 15 \mathrm{~mm}$. Although this approach incurs the least increase in concrete cost (compared to SF or SBR additions), it is worth noting that the decreased mixing water considerably increased the mixture cohesiveness, which could alter the pumpability and casting procedures on-site [38]. Additionally, the concrete proneness to instability and bleeding increased with higher HRWR [29,39], which led to a visible bleed layer on top of concrete cylinders. Two SBR dosages of $7.5 \%$ or $15 \%$ by mixing water are considered; the resulting polymer-to-cement ratio (p/c) was $2.24 \%$ and $4.48 \%$, respectively. It is to be mentioned that $\mathrm{p} / \mathrm{c}$ could reach $10 \%$ in certain repair and precast applications; however, 
such high rates would dramatically alter cement hydration kinetics and rates of strength development $[25,30,31]$. Finally, the SF was added at $0.4 \%$ or $0.8 \%$ by concrete volume, while the HRWR was adjusted to keep similar workability.

The RCA concrete was prepared by fully (i.e., 100\%) replacing the NCA with recycled aggregates (Table 1); the resulting 28-days $\mathrm{f}^{\prime} \mathrm{C}$ was $31.34 \mathrm{MPa}$. The PET particles are introduced at $3 \%$ by the total concrete volume, given that higher rates significantly degraded the concrete strength. Three mixtures are then prepared either by reducing w/c to 0.46 or by incorporating SBR or SF. As earlier, the sand-to-total aggregate ratio remained fixed at 0.45 , while the HRWR adjusted for the fixed slump of $200 \pm 15 \mathrm{~mm}$.

\subsection{Concrete Mixing}

The amount of mixing water for concrete batching was computed to compensate for the moisture and water absorption levels of sand and coarse aggregates (i.e., NCA and RCA) used. The aggregates were mixed with approximately $50 \%$ of mixing water for $10-\mathrm{min}$ before the commencement of batching since most of the water absorption occurs within this time interval $[18,40]$. The procedure for concrete batching consisted of homogenizing the fine and coarse aggregates together with the PET and steel fibers for about $1 \mathrm{~min}$. The cement was then introduced, followed by the remaining mixing water, SBR latex, and HRWR over a period of $2 \mathrm{~min}$. After a resting period of $30 \mathrm{~s}$, the concrete is remixed for one additional minute. Testing and sampling are conducted at room temperature of $22 \pm 3{ }^{\circ} \mathrm{C}$ and relative humidity of $60 \pm 10 \%$.

\subsection{Testing Methods}

Right after mixing, the slump and air content were determined as per ASTM C143 and C231, respectively [41,42]. The concrete is then filled in $100 \mathrm{~mm} \times 200 \mathrm{~mm}$ steel cylinders to determine the hardened density $(\rho), \mathrm{f}^{\prime} \mathrm{c}$, splitting tensile strength $(\mathrm{ft})$, and ultrasonic pulse velocity (UPV) as per ASTM C642, C39, C496, and C597, respectively [43-46]. All specimens were immersed in water for 3 days, then moist cured at $95 \% \pm 5 \%$ relative humidity $(\mathrm{RH})$ and $22 \pm 3{ }^{\circ} \mathrm{C}$ for testing age after 28 days. Earlier studies showed that this curing regime is appropriate to maintain a minimum $\mathrm{RH}$ of $90 \%$ for proper strength development of unmodified concrete while preventing destabilization of SBR polymer films due to a complete soaking of specimens in water [39]. The load was gradually applied at rates hovering 0.2 and $0.02 \mathrm{MPa} / \mathrm{s}$ for $\mathrm{f}^{\prime} \mathrm{c}$ and $\mathrm{ft}$ testing, respectively. The modulus of elasticity (E) was deducted from the UPV measurements using the conventional equation for wave propagation in solid rocks given as: $\mathrm{E}, \mathrm{GPa}=\left[\rho \times \mathrm{UPV}^{2} / \mathrm{g}\right] 10^{-2}$, where $\mathrm{g}$ is the gravity acceleration. Averages of three values are considered in this program.

The sorptivity (or, rate of water absorption) is evaluated as per ASTM C1585 [47]. Prior to testing, the $100-\mathrm{mm}$ diameter and $50 \mathrm{~mm}$ length concrete slices are oven-dried at $50 \pm 3{ }^{\circ} \mathrm{C}$ to constant mass. After cooling, the specimen sides are covered by a thin resin layer to prevent evaporation, while the exposed surface is immersed in $2 \pm 1 \mathrm{~mm}$ depth water to determine the increase in mass over time. The initial sorptivity $\left(\mathrm{Wi}, \mathrm{mm} / \mathrm{min}^{1 / 2}\right.$ ) is the slope of the straight line fitted within the data recorded during the first six hours of readings, while the secondary sorptivity (Ws, $\mathrm{mm} / \mathrm{min}^{1 / 2}$ ) is computed between 1 and 7 days.

The drying shrinkage is determined by means of a dial gauge extensometer using $75 \mathrm{~mm} \times 75 \mathrm{~mm} \times 254 \mathrm{~mm}$ prisms, as per ASTM C157 [48]. The specimens are demolded after $24 \mathrm{~h}$ of casting, then stored in a cabinet where ambient temperature and $\mathrm{RH}$ are set to $23 \pm 2{ }^{\circ} \mathrm{C}$ and $50 \% \pm 5 \%$, respectively. Measurements are made every day during the first week; then twice every week until 45 days of age.

The effect of PET additions on the concrete bond stress-slip properties to embedded reinforcement was assessed using the direct bond method, as per RILEM/CEB/FIB recommendations [49]. The freshly mixed concrete was poured in 150-mm cubic molds, with the $10-\mathrm{mm} \mathrm{d}_{\mathrm{b}}$ bars vertically centered before casting (Figure 2 ). The embedded bar length was $50 \mathrm{~mm}$ (i.e., $5 \mathrm{~d}_{\mathrm{b}}$ ), and a PVC bond breaker was inserted around the reinforcement at the 
concrete surface. All specimens were placed in polyethylene bags for curing at $22 \pm 3{ }^{\circ} \mathrm{C}$ and about 95\% RH. The direct bond test performed using a universal testing machine consisted of recording the pullout load and relative slips of the steel bar, while encasing the concrete block against the steel reaction frame. The load was gradually applied at a constant rate hovering $0.25 \mathrm{kN} / \mathrm{s}$. It is worth noting that the direct bond test is widely used because of its simplicity [19,30], albeit it might not mimic actual conditions (i.e., large concrete cover around the steel) and the nature of stresses encountered in flexural members.
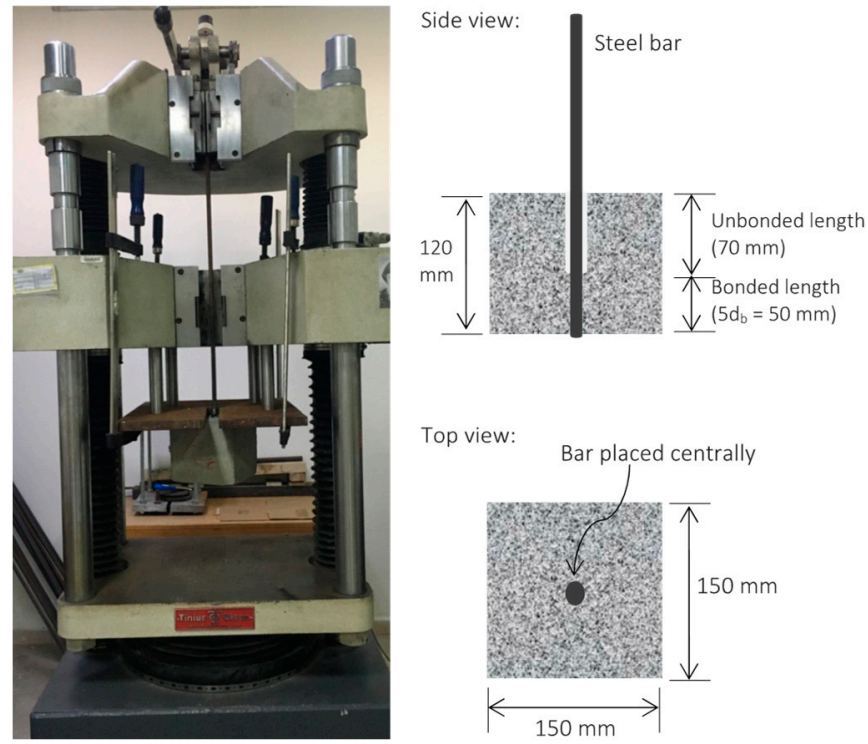

Figure 2. Photo and sketch for the set-up used for direct bond testing.

\section{Test Results and Discussion}

\subsection{Hardened Concrete Properties}

Table 2 summarizes the air content, density, and hardened properties of investigated mixtures. In general, the concrete density decreased with PET, given the lightweight nature of such additions $[7,8]$. The air content varied within $2.8 \% \pm 0.5 \%$, albeit the highest values were recorded for mixtures containing SBR latex. This can be attributed to the presence of anionic surfactants used to stabilize the polymers in the aqueous solution, including their inherent ability to reduce the surface tension of water and generate tiny bubbles during mixing [25].

The repeatability of test responses was evaluated by batching several times the 3\% PET-modified mixtures; a new batch was made each time. In general, the coefficient of variation (COV) degraded with PET additions, particularly when used in conjuncture with SBR. For example, the COV for $\mathrm{f}^{\prime} \mathrm{c}$ responses increased from $5.7 \%$ for the control concrete to $7.7 \%$ with PET additions, and then to $10.2 \%$ when the PET and SBR are both incorporated in the same mixture. Such values varied from $6.6 \%$ to $9 \%$ and $9.6 \%$, respectively, for $\mathrm{ft}$ measurements. This may be attributed to the light PET nature and poor bonding to the cementitious phase that could alter the spatial aggregate distribution and isotropic strength of cast specimens. Additionally, the shredded PET pieces had irregular shapes with varying sizes between 1 to $6 \mathrm{~mm}$, which could significantly increase the variability of test results. The curtail in repeatability due to SBR can be associated with adsorption/coalescence polymer phenomena that possibly change the kinetics of cement hydration and strength development $[26,31]$. 
Table 2. HRWR demand, density, and hardened concrete properties.

\begin{tabular}{|c|c|c|c|c|c|c|c|c|c|c|}
\hline & $\begin{array}{l}\text { HRWR, \% } \\
\text { of Cement }\end{array}$ & $\underset{\text { Air }}{\text { Content, } \%}$ & $\begin{array}{l}\text { Density, } \\
\mathrm{kg} / \mathrm{m}^{3}\end{array}$ & $\mathbf{f}^{\prime} \mathrm{c}, \mathrm{MPa}$ & $\mathrm{ft}, \mathrm{MPa}$ & $\begin{array}{l}\text { UPV, } \\
\mathrm{km} / \mathrm{s}\end{array}$ & E, GPa & $\begin{array}{l}\mathrm{Wi}, \\
\mathrm{mm} / \mathrm{s}\end{array}$ & $\begin{array}{c}\mathrm{Ws}, \\
\mathrm{mm} / \mathrm{s}\end{array}$ & $\begin{array}{c}\text { Shrink, } \\
\mu \mathrm{m}\end{array}$ \\
\hline NCA & 1.52 & 2.7 & 2345 & 35.43 & 3.87 & 3.72 & 33.08 & 0.117 & 0.039 & 513 \\
\hline NCA-1.5\% PET & 1.57 & $\mathrm{n} / \mathrm{a}$ & 2340 & 36.23 & 3.96 & 3.6 & 30.91 & 0.12 & 0.036 & 526 \\
\hline NCA-3\% PET & 1.65 & 2.5 & 2305 & 33.27 & 3.53 & 3.52 & 29.11 & 0.101 & 0.031 & 595 \\
\hline NCA- $4.5 \%$ PET & 2.09 & 3.1 & 2270 & 29.57 & 2.88 & 3.38 & 26.44 & 0.135 & 0.05 & 642 \\
\hline NCA- $4.5 \%$ PET- $0.46 \mathrm{w} / \mathrm{c}$ & 3.29 & 2.8 & 2310 & 36.03 & 3.65 & 3.67 & 31.72 & 0.122 & 0.034 & 455 \\
\hline NCA- $3 \%$ PET- $0.4 \%$ SF & 1.77 & $\mathrm{n} / \mathrm{a}$ & 2295 & 31.85 & 4.01 & 3.55 & 29.48 & $\mathrm{n} / \mathrm{a}$ & $\mathrm{n} / \mathrm{a}$ & $\mathrm{n} / \mathrm{a}$ \\
\hline NCA-3 $\%$ PET- $0.8 \%$ SF & 1.76 & 3 & 2315 & 32.28 & 4.42 & 3.48 & 28.58 & 0.102 & 0.033 & 566 \\
\hline NCA- $4.5 \%$ PET- $0.8 \%$ SF & 2.19 & $\mathrm{n} / \mathrm{a}$ & 2265 & 28.59 & 3.57 & 3.4 & 26.69 & 0.140 & 0.045 & 604 \\
\hline NCA- $4.5 \%$ PET- $7.5 \%$ SBR & 1.91 & 3.3 & 2270 & 23.9 & 3.25 & 3.33 & 25.66 & 0.108 & 0.033 & 548 \\
\hline NCA- $4.5 \%$ PET- $15 \%$ SBR & 1.74 & $\mathrm{n} / \mathrm{a}$ & 2255 & 23.29 & 3.79 & 3.45 & 27.36 & 0.093 & 0.028 & 470 \\
\hline RCA & 1.76 & 2.3 & 2265 & 31.34 & 3.34 & 3.46 & 27.64 & 0.152 & 0.048 & $\mathrm{n} / \mathrm{a}$ \\
\hline RCA-1.5\% PET & 1.81 & $\mathrm{n} / \mathrm{a}$ & 2250 & 29.55 & 3.44 & 3.44 & 27.14 & 0.148 & 0.051 & $\mathrm{n} / \mathrm{a}$ \\
\hline RCA-3\% PET & 2.05 & $\mathrm{n} / \mathrm{a}$ & 2205 & 27.07 & 3.04 & 3.27 & 24.03 & 0.13 & 0.043 & $\mathrm{n} / \mathrm{a}$ \\
\hline RCA-3\% PET- $0.46 \mathrm{w} / \mathrm{c}$ & 3.71 & 2.4 & 2290 & 34.36 & 3.51 & 3.62 & 30.59 & 0.123 & 0.037 & $\mathrm{n} / \mathrm{a}$ \\
\hline RCA-3 $\%$ PET- $0.8 \%$ SF & 2.29 & $\mathrm{n} / \mathrm{a}$ & 2220 & 29.04 & 4.03 & 3.51 & 27.88 & 0.153 & 0.051 & $\mathrm{n} / \mathrm{a}$ \\
\hline RCA-3\% PET-15\% SBR & 2.19 & 3.2 & 2205 & 25.78 & 3.64 & 3.36 & 25.38 & 0.101 & 0.03 & $\mathrm{n} / \mathrm{a}$ \\
\hline
\end{tabular}

Slump varied between 185 and $210 \mathrm{~mm}$. $\mathrm{n} / \mathrm{a}$ refers to not measured.

\subsection{1. $\mathrm{f}^{\prime} \mathrm{c}$, $\mathrm{ft}$, and E Responses for NCA Mixtures}

During the discussion, the variations in hardened properties due to PET additions (i.e., $\Delta$ (Property)) is computed as follows:

$$
\Delta(\text { Property })=\frac{[\text { Property of PET modified concrete }- \text { Property of control mix }]}{\text { Property of control mix }} \times 100
$$

Figure 3 plots the $\Delta\left(\mathrm{f}^{\prime} \mathrm{c}\right.$, ft, and $\left.\mathrm{E}\right)$ for NCA mixtures. As expected, the concrete strength and modulus of elasticity decreased with PET additions, given their lightweight nature and poor characteristic strength compared to aggregate particles. For example, the $\Delta\left(f^{\prime} \mathrm{c}\right)$ varied from $-6.1 \%$ to $-16.5 \%$ for $3 \%$ PET and $4.5 \%$ PET mixtures, respectively. The corresponding $\Delta(\mathrm{E})$ was $-12 \%$ and $-20.1 \%$, respectively, while $\Delta(\mathrm{ft})$ was $-8.9 \%$ and $-25.7 \%$, respectively. The drop in tensile properties could be related to poor bonding with the cementitious mortar matrix, thus weakening the resistance against crack propagation during loading $[5,12]$. This was visually verified when inspecting the broken cylinders since the failure planes were visible along with the PET interfaces.

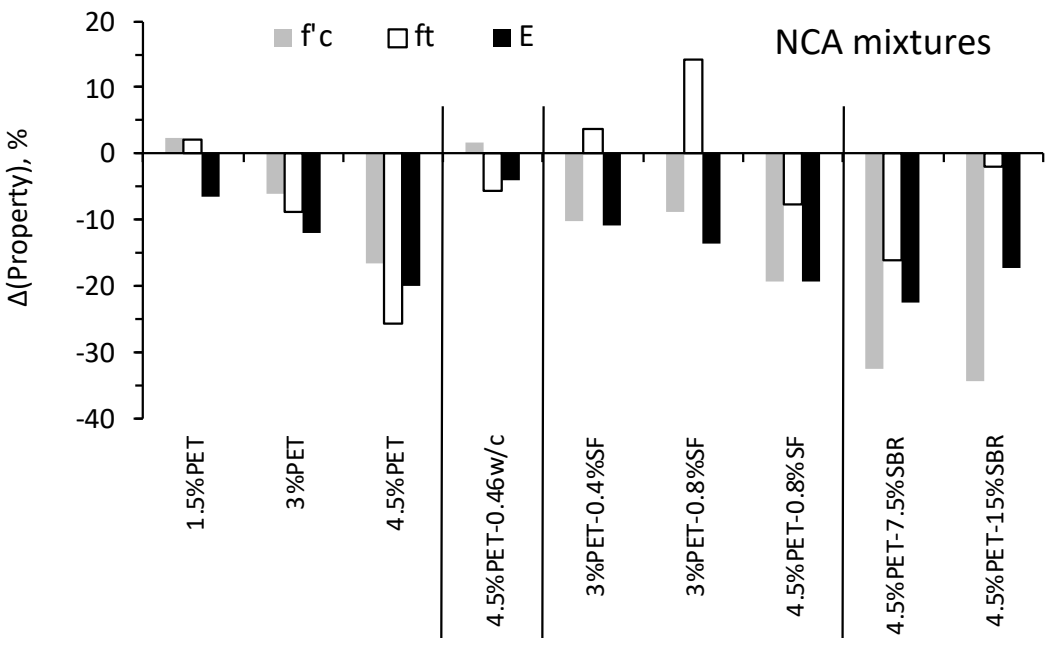

Figure 3. Effect of PET additions on $\Delta\left(\mathrm{f}^{\prime} \mathrm{c}\right.$, ft, and $\left.\mathrm{E}\right)$ for NCA concrete mixtures. 
As shown in Figure 3, the reduction in w/c from 0.55 to 0.46 was efficient to compensate for the drop in strength due to $4.5 \%$ PET, which can naturally be attributed to reduced matrix porosity and refined microstructure [50]. The corresponding $\Delta\left(\mathrm{f}^{\prime} \mathrm{c}\right)$ and $\Delta(\mathrm{ft})$ reached $1.69 \%$ and $-5.7 \%$, respectively. As earlier noted, the attempts to further reduce w/c were not successful, given the increased HRWR demand that detrimentally altered concrete stability and resistance to bleeding. At the 3\% PET rate, the curtail in $\mathrm{ft}$ responses was fully recovered by the incorporation of SF; hence, the $\Delta(\mathrm{ft})$ reached $3.7 \%$ and $14.2 \%$ for the $3 \%$ PET- $0.4 \%$ SF and 3\% PET- $0.8 \%$ SF, respectively. This can be directly attributed to the presence of fibers that are known by their efficiency to delay the formation of cracks, or at least arrest their initial growth during tensile loading [24,29]. Nevertheless, despite the use of $0.8 \% \mathrm{SF}$, the loss in strength for the $4.5 \%$ PET-modified concrete was not recovered, suggesting that this could be the threshold rate incorporated in concrete mixtures. Hence, the corresponding $\Delta\left(\mathrm{f}^{\prime} \mathrm{c}\right)$ and $\Delta(\mathrm{ft})$ were $-19.3 \%$ and $-7.6 \%$, respectively.

The addition of SBR differently affected the compression and tensile-related properties (Figure 3), which is consistent with current literature $[25,26,31]$. Hence, the drop in $\mathrm{f}^{\prime} \mathrm{c}$ can be attributed to the presence of surfactants as well as the elastic nature of the polymer films that weaken the resistance of the cement matrix to compression loading. In contrast, the $\Delta(\mathrm{ft})$ gradually improved to $-16.1 \%$ for the $4.5 \%$ PET- $7.5 \%$ SBR, and then became close to zero for the $4.5 \%$ PET-15\% SBR. Ohama [25] reported that the hardened cementitious structure is bound by van der Waals forces that weaken the tensile properties due to micro-crack formation. Such weakness can be compensated in latex-modified systems, given the coalesced polymer films that impede the initiation of cracks and strengthen the cement-aggregate interfacial transition zones (ITZs). Wang et al. [31] suggested that the improved smoothness of latex-modified concrete can reduce the porosity of ITZs, thus creating a stronger bond by micro-mechanical interlocking mechanisms.

\subsubsection{Effect of RCA}

As shown in Figure 4, the concrete strength degraded by about $10 \%$ when the NCA was replaced by RCA, which can naturally be associated with the lower density and weaker aggregate properties $[18,19]$. The $\Delta\left(\mathrm{f}^{\prime} \mathrm{c}\right)$ and $\Delta(\mathrm{ft})$ dropped respectively to $-23.6 \%$ and $-21.5 \%$ with $3 \%$ PET, given the conjuncture detrimental effect of such additions and RCA on concrete properties. As earlier noted, the preliminary tests showed the concrete strength could significantly drop (i.e., beyond 35\%) at higher PET rates, suggesting that 3\% is the threshold PET rate for mixtures prepared with RCA materials.

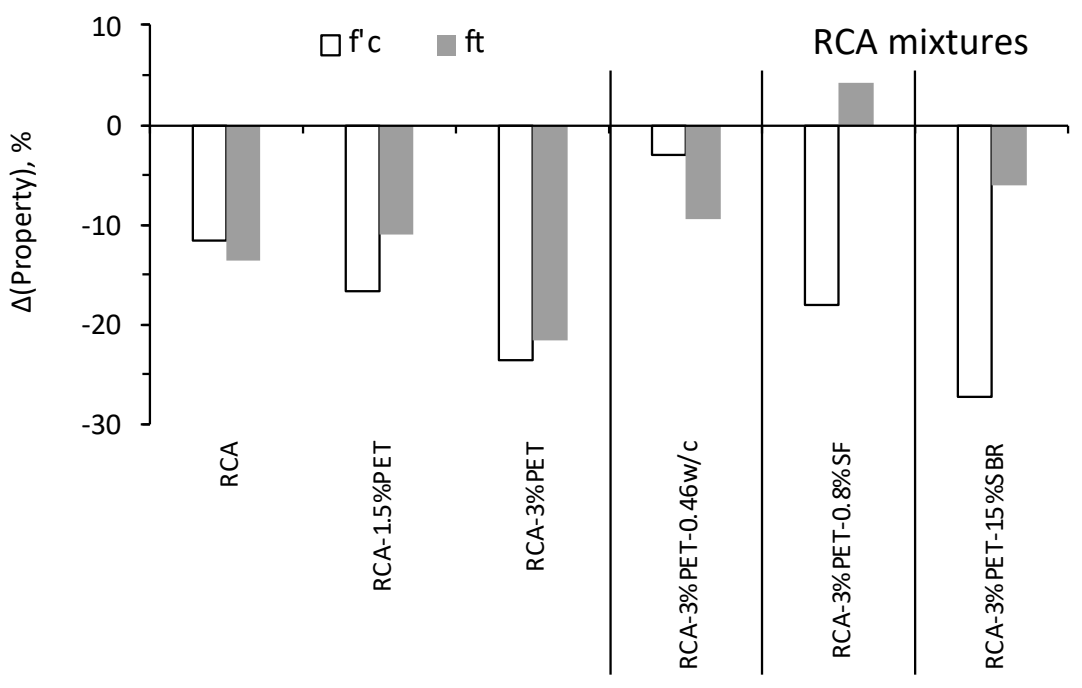

Figure 4. Effect of PET additions on $\Delta\left(\mathrm{f}^{\prime} \mathrm{c}\right.$ and $\left.\mathrm{ft}\right)$ for RCA concrete mixtures.

Just like NCA mixtures, the reduction of w/c from 0.55 to 0.46 was beneficial to improve the strength of concrete containing RCA; the resulting $\Delta\left(\mathrm{f}^{\prime} \mathrm{c}\right)$ and $\Delta(\mathrm{ft})$ were $-3 \%$ 
and $-9.4 \%$, respectively. On the other hand, the incorporation of SF or SBR was mainly efficient to enhance $\mathrm{ft}$, given their beneficial effect on the tensile-related properties. The resulting $\Delta(\mathrm{ft})$ was $4.2 \%$ and $-6 \%$ for the mixtures containing $0.8 \%$ SF and $15 \%$ SBR, respectively. The relationships between $\mathrm{f}^{\prime} \mathrm{c}$ with respect to $\mathrm{E}$ and density for all tested mixtures are expressed in Equations (1) and (2); note that a weak correlation with $\mathrm{R}^{2}$ less than 0.1 exists between $\mathrm{f}^{\prime} \mathrm{c}$ and $\mathrm{ft}$, given the SBR and SF opposing modes of action on the compression and tensile-related properties.

$$
\begin{gathered}
\mathrm{f}^{\prime} \mathrm{c}, \mathrm{MPa}=1.43(\mathrm{E}, \mathrm{GPa})-10.07 \mathrm{R}^{2}=0.72 \\
\mathrm{f}^{\prime} \mathrm{c}, \mathrm{MPa}=0.0764\left(\rho, \mathrm{kg} / \mathrm{m}^{3}\right)-143.44 \mathrm{R}^{2}=0.62
\end{gathered}
$$

\subsubsection{Sorptivity}

Figure 5 plots the variations in sorptivity for various NCA mixtures. At relatively low concentrations (i.e., 1.5\% and 3\%), PET additions seem to play a beneficial role to constitute internal barriers against water ingress, which reduced the sorptivity measurements [10,51]. Yet, the $\Delta(\mathrm{Wi})$ and $\Delta(\mathrm{Ws})$ remarkably increased to $14.7 \%$ and $27.9 \%$, respectively, at a higher PET rate of $4.5 \%$. Such results agree with the strength responses, suggesting that increased additions require appropriate modifications to compensate for their negative impact on the concrete properties.

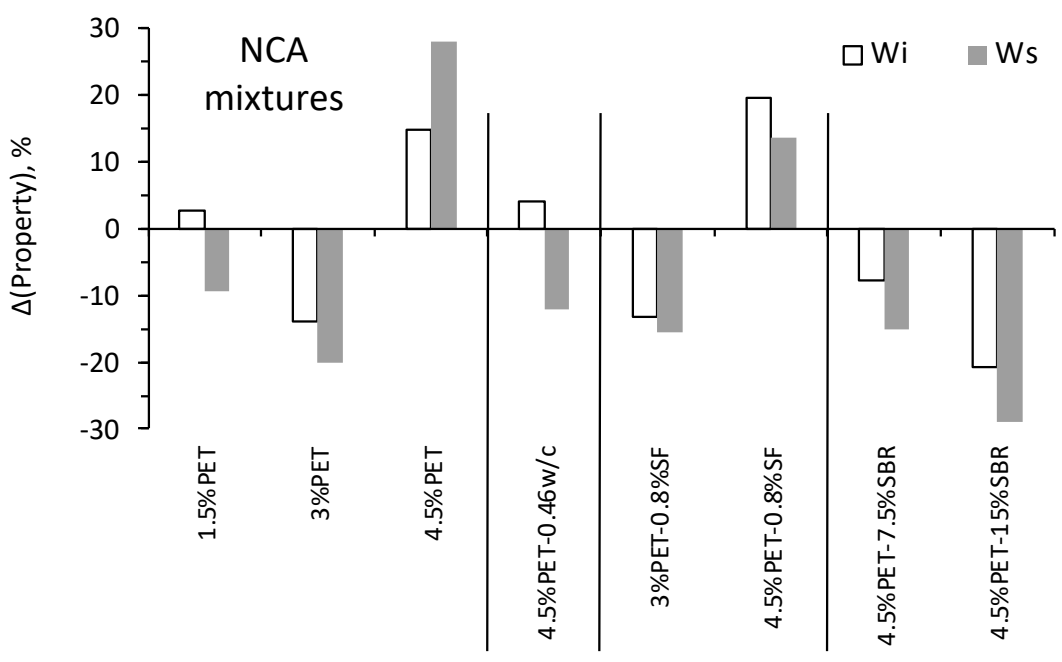

Figure 5. Effect of PET additions on $\Delta$ (Sorptivity) for NCA concrete mixtures.

As shown in Figure 5, the reduction in w/c and/or incorporation of SBR are quite efficient to fully reinstate the concrete resistance against water ingress. Hence, $\Delta(\mathrm{Ws})$ dropped to $-12.1 \%$ and $-29 \%$ for the $4.5 \%$ PET- $0.46 \mathrm{w} / \mathrm{c}$ and $4.5 \%$ PET- $15 \%$ SBR mixtures, respectively. The reduced sorptivity due to SBR modification can be related to the hydrophilic latex properties that form a network structure of impermeable films, thus blocking and sealing the capillary pores within the cementitious matrix [25]. In contrast, however, the addition of SF does not seem efficient to attenuate the high sorptivity of $4.5 \%$ PET-modified concrete; the resulting $\Delta(\mathrm{Wi})$ and $\Delta(\mathrm{Ws})$ were $19.6 \%$ and $13.6 \%$, respectively.

\subsubsection{Drying Shrinkage}

Typical plots showing the variations in drying shrinkage over time for the control and 4.5\% PET mixtures are given in Figure 6. All curves reflected a gradual increase in shrinkage during the first 2 weeks of measurements, which thereafter tended to stabilize at different levels depending on the concrete composition. Hence, the 45-days shrinkage remarkably increased from $513 \mu$ strain for the control mix to 595 and $642 \mu$ strain for mixtures containing $3 \%$ or $4.5 \%$ PET, respectively. Earlier studies associated the increase in shrinkage due to 
plastic wastes with reduced concrete stiffness as well as smoother interfaces along with the PET particles that could promote shrinkage of the cementitious matrix [5,11,12].

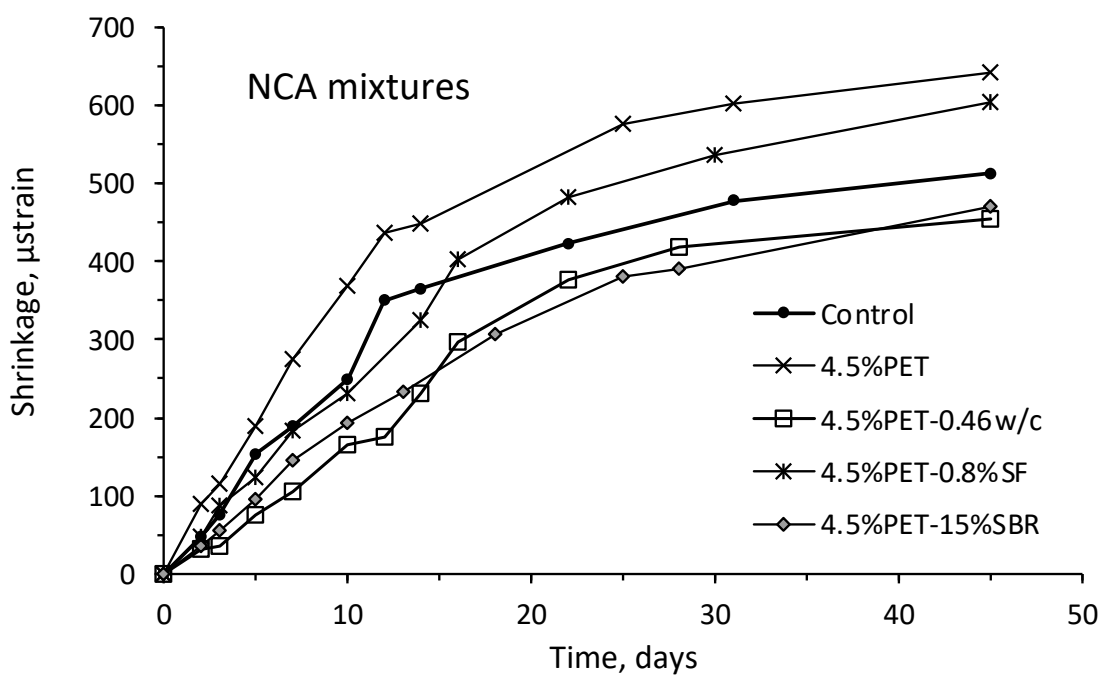

Figure 6. Variations of drying shrinkage over time for control and 4.5\% PET-modified concrete.

Just like the sorptivity, the increase in shrinkage due to PET additions can be compensated by reducing $\mathrm{w} / \mathrm{c}$ or incorporating SBR polymers. Hence, the 45-days shrinkage level dropped to 455 and $470 \mu$ strain for $4.5 \%$ PET- $0.46 \mathrm{w} / \mathrm{c}$ and $4.5 \%$ PET-15\% SBR, respectively (Table 2). The former phenomenon can be attributed to refined concrete porosity and strength due to reduced $\mathrm{w} / \mathrm{c}$, while the sealing effect of the capillary pores due to polymer films adsorption can hinder the ease of water evaporation and reduce the extent of drying shrinkage. As shown in Figure 6, the addition of SF had a limited effect on shrinkage, and the 45 days level was found to be $604 \mu$ strain.

\subsection{Concrete Bond Stress-Slip Behavior}

All specimens exhibited a pullout mode of failure, with no signs of cracks on the exterior concrete surface or bar yielding. This reflects adequate rebar confinement by the concrete cover, which is consistent with the RILEM/CEB/FIB design [49]. The failure occurred dynamically due to the shearing of concrete along the embedded bar length of $5 \mathrm{~d}_{\mathrm{b}}$. Table 3 summarizes the ultimate bond stress $\left(\tau_{\max }\right)$ and corresponding slip at failure; the $\tau_{\max }$ is computed as the maximum pullout load that caused failure divided by the sheared concrete area that is taken as $2 \pi \frac{d_{b}}{2} L$, where $L$ is the embedment length.

\subsubsection{Bond Stress vs. Slip Curves}

Typical bond stress vs. slip curves determined for the control NCA concrete and those containing different PET concentrations are plotted in Figure 7; the plot related to the mixture prepared with reduced $\mathrm{w} / \mathrm{c}$ is also shown. All curves followed the same trend characterized by three distinct regions including a linear increase in the pre-peak region where the transfer of stresses mostly occurs due to the adhesive and mechanical interlock components, $\tau_{\max }$ reflecting failure, and a gradual decay in the post-peak region where only the frictional component of the bond remains $[27,30]$. The $\tau_{\max }$ slightly increased from 14.1 MPa for the control NCA concrete to 15.4 and $15.1 \mathrm{MPa}$ at $1.5 \%$ and $3 \%$ PET rates, respectively, which may be attributed to some bridging effects that limited the radial cracks around the reinforcing bars [24,52]. Yet, at an increased rate of $4.5 \%, \tau_{\max }$ dropped to 13.6 MPa due to reduced density and weakened concrete skeleton. In the case of concrete prepared with RCA, $\tau_{\max }$ decreased to $12.3 \mathrm{MPa}$ with $3 \%$ PET additions, which can be attributed to the coupled detrimental effects of RCA and waste plastics on strength development. Such results concord with the previous results, highlighting the importance of mitigating the negative impact of PET additions on concrete properties. 
Table 3. Concrete bond properties to embedded steel bars.

\begin{tabular}{|c|c|c|c|c|c|c|}
\hline & \multicolumn{2}{|c|}{ Experimental Testing } & \multicolumn{2}{|c|}{ ACI 318-19 Model } & \multicolumn{2}{|c|}{ CEB-FIP Model } \\
\hline & $\tau_{\max }, \mathrm{MPa}$ & Slip, mm & $\tau_{\mathbf{u}}, \mathrm{MPa}$ & $\tau_{\max } / \tau_{\mathbf{u}}$ & $\tau_{\mathbf{u}}, \mathrm{MPa}$ & $\tau_{\max } / \tau_{\mathrm{u}}$ \\
\hline NCA & 14.1 & 3.93 & 5.17 & 2.72 & 11.9 & 1.18 \\
\hline NCA-1.5\% PET & 15.4 & 4.33 & 5.22 & 2.95 & 12.04 & 1.28 \\
\hline NCA-3\% PET & 15.1 & 4.96 & 5.01 & 3.01 & 11.54 & 1.31 \\
\hline NCA- $4.5 \%$ PET & 13.6 & 4.42 & 4.72 & 2.88 & 10.88 & 1.25 \\
\hline NCA-4.5\% PET-0.46 w/c & 14.8 & 4.1 & 5.21 & 2.84 & 12 & 1.23 \\
\hline NCA-3\% PET- $0.8 \%$ SF & 18.5 & 5.64 & 4.93 & 3.75 & 11.36 & 1.63 \\
\hline NCA- $4.5 \%$ PET- $0.8 \%$ SF & 14.7 & 5.02 & 4.64 & 3.17 & 10.69 & 1.37 \\
\hline NCA-4.5\% PET-15\% SBR & 15.6 & 4.66 & 4.19 & 3.73 & 9.65 & 1.62 \\
\hline RCA & 12.9 & 3.47 & 4.86 & 2.65 & 11.2 & 1.15 \\
\hline RCA-1.5\% PET & 13.1 & 4.5 & 4.72 & 2.78 & 10.87 & 1.2 \\
\hline RCA-3\% PET & 12.3 & 4.24 & 4.52 & 2.71 & 10.41 & 1.18 \\
\hline RCA-3\% PET-0.46 w/c & 14.3 & 4.48 & 5.09 & 2.81 & 11.72 & 1.22 \\
\hline RCA-3\% PET-0.8\% SF & 15.2 & 5.23 & 4.68 & 3.25 & 10.78 & 1.41 \\
\hline RCA-3\% PET-15\% SBR & 15.5 & 5.6 & 4.41 & 3.51 & 10.16 & 1.52 \\
\hline
\end{tabular}

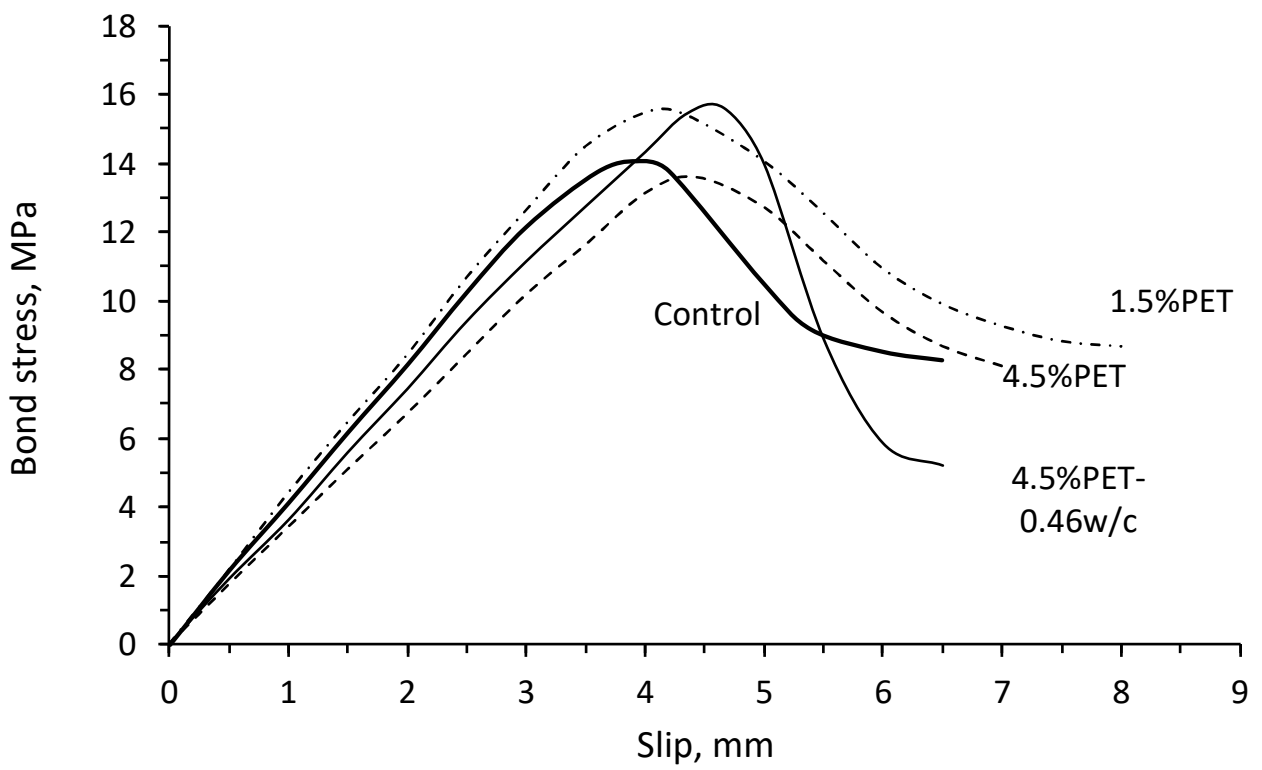

Figure 7. Typical bond vs. slip curves for the control and PET-modified concrete.

Regardless of the aggregate type (NCA or RCA), the slip at failure increased with PET additions. For example, this varied from $3.93 \mathrm{~mm}$ for the control NCA concrete to 4.96 and $4.24 \mathrm{~mm}$ for the NCA-3\% PET and RCA-3\% PET mixtures, respectively. Similar results are reported by other researchers when testing the bond properties of concrete mixtures containing plastic wastes [27-29]. This was associated with the reduced modulus of elasticity that promotes strain softening, which may be relevant in certain conditions to attenuate the brittle failure of structural members subjected to reversed cyclic loading [50]. A moderate relationship with $\mathrm{R}^{2}$ of 0.52 exists between $\tau_{\max }$ and slip at failure (Figure 8); hence, mixtures possessing higher bond strengths exhibited higher slips at failure. 


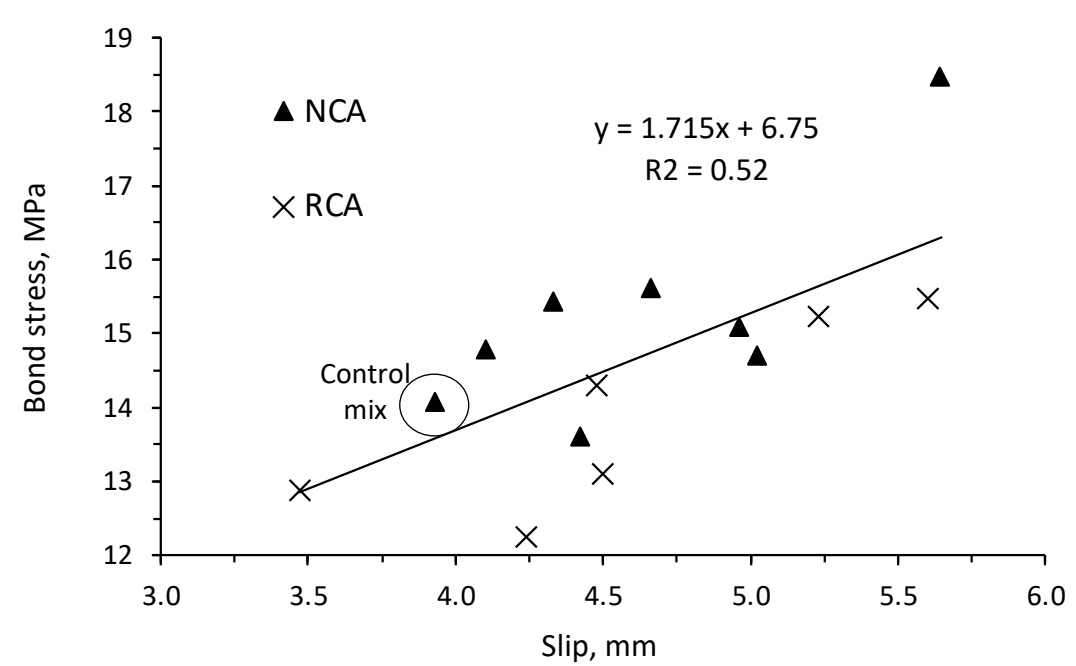

Figure 8. Relationship between the bond strength and slip at failure for all tested mixtures.

\subsubsection{Effect of Concrete Modification}

Figure 9 plots the effect of concrete modifications on $\Delta\left(\tau_{\max }\right)$ and $\Delta$ (Slip) for various NCA and RCA mixtures. As shown, the reduction in w/c was efficient in fully restoring the bond properties of the NCA- $4.5 \%$ PET or RCA-3\% PET concrete; the resulting $\Delta\left(\tau_{\max }\right)$ was $5.1 \%$ or $1.6 \%$, respectively, with the corresponding $\Delta$ (Slip) of $4.3 \%$ and $14 \%$, respectively. This can normally be related to the reduced free mixing water that decreases the concrete porosity within the rib interfaces, leading to increased bond strengths. The beneficial effect of reduced $\mathrm{w} / \mathrm{c}$ on the strength development of mixtures containing plastic wastes is well documented by other scholars $[24,29,51]$. Nevertheless, as earlier noted, this approach entails adjusting the HRWR dosage to compensate for the loss in workability, which could alter concrete stability (i.e., mostly cohesiveness and bleeding) and casting procedures on site.

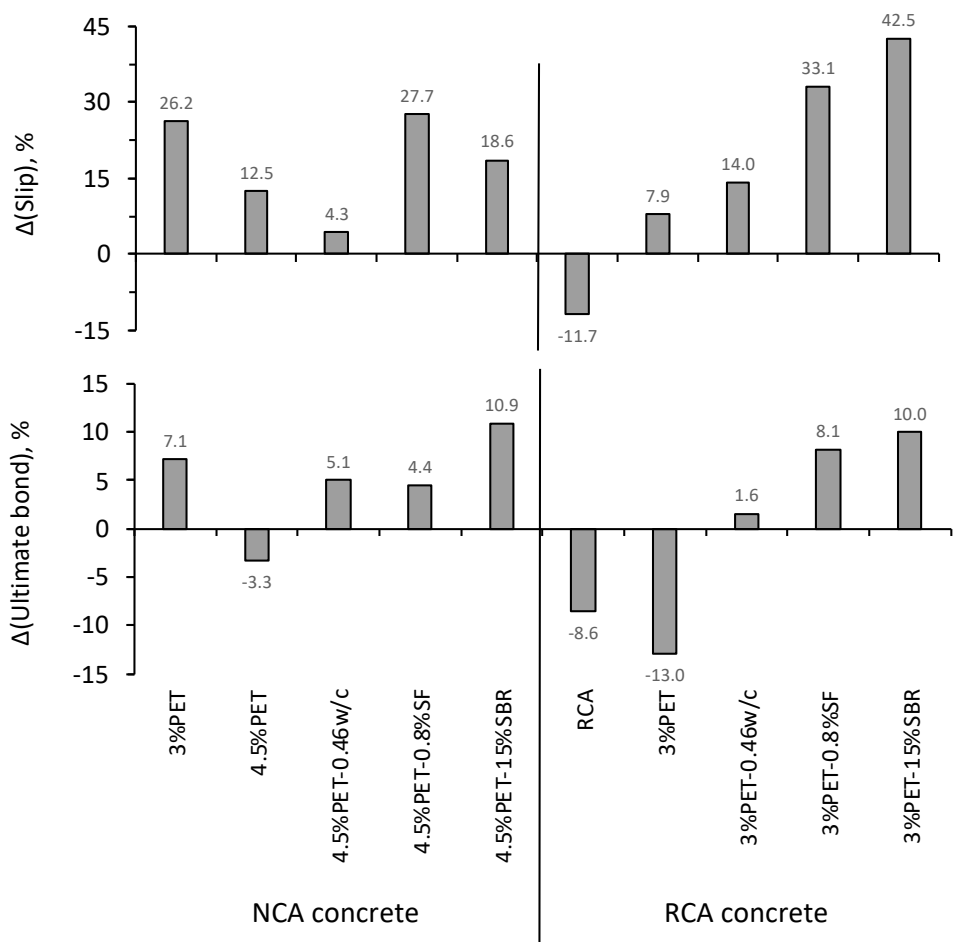

Figure 9. Effect of concrete modification on $\Delta\left(\tau_{\max }\right)$ and $\Delta($ Slip $)$ for NCA and RCA concrete. 
As shown in Figure 9, the incorporation of $0.8 \%$ steel fibers or $15 \%$ SBR polymers significantly enhanced the bond properties, as compared to mixtures prepared with reduced $\mathrm{w} / \mathrm{c}$. For example, $\Delta\left(\tau_{\max }\right)$ reached respectively $4.4 \%$ and $8.1 \%$ for the NCA-4.5\% PET and RCA-3\% PET mixtures containing $0.8 \%$ SF; the corresponding $\Delta$ (Slip) was $27.7 \%$ and $33.1 \%$, respectively. The bond enhancement in the case of fiber modification is in line with many studies that attributed this behavior to increased confinement and fiber bridging effects that limited the initiation of cracks in the vicinity of the reinforcing bars. Several scholars [52-54] reported that SF reduced the crack propagation during pullout loading, leading to enhanced energy dissipation, post-cracking, and ductility. It is worth noting that the highest slip at the failure of $5.64 \mathrm{~mm}$ corresponded for the NCA-3\% PET-0.8\% SF mix, given the fibers' bridging effect that reduced the initiation and propagation of cracks.

In the case of $15 \%$ SBR modification, the $\Delta\left(\tau_{\max }\right)$ reached respectively $10.9 \%$ and $10 \%$ for the NCA-4.5\% PET and RCA-3\% PET mixtures (Figure 9). Earlier studies showed that the polymeric latexes can fuse and coalesce in the cement matrix to create polymer films that strengthen the adhesive component of the bond along the reinforcement steel ribs $[25,26]$. Concurrently, the reduced bleeding and percolation of polymer-modified concrete minimize the risks of accumulating free mixing water around the steel bars, leading to reduced interfacial porosity and enhanced bond strength. The highest $\Delta$ (Slip) of $42.5 \%$ corresponded to the RCA-3\% PET concrete containing $15 \%$ SBR additions. A moderate relationship with $\mathrm{R}^{2}$ of 0.69 exists between $\tau_{\max }$ and splitting tensile strength for all tested mixtures (Figure 10). The correlation drops significantly when the $\mathrm{f}^{\prime} \mathrm{c}$ responses are used, reflecting that the bond and compressive strength are not related within each other.

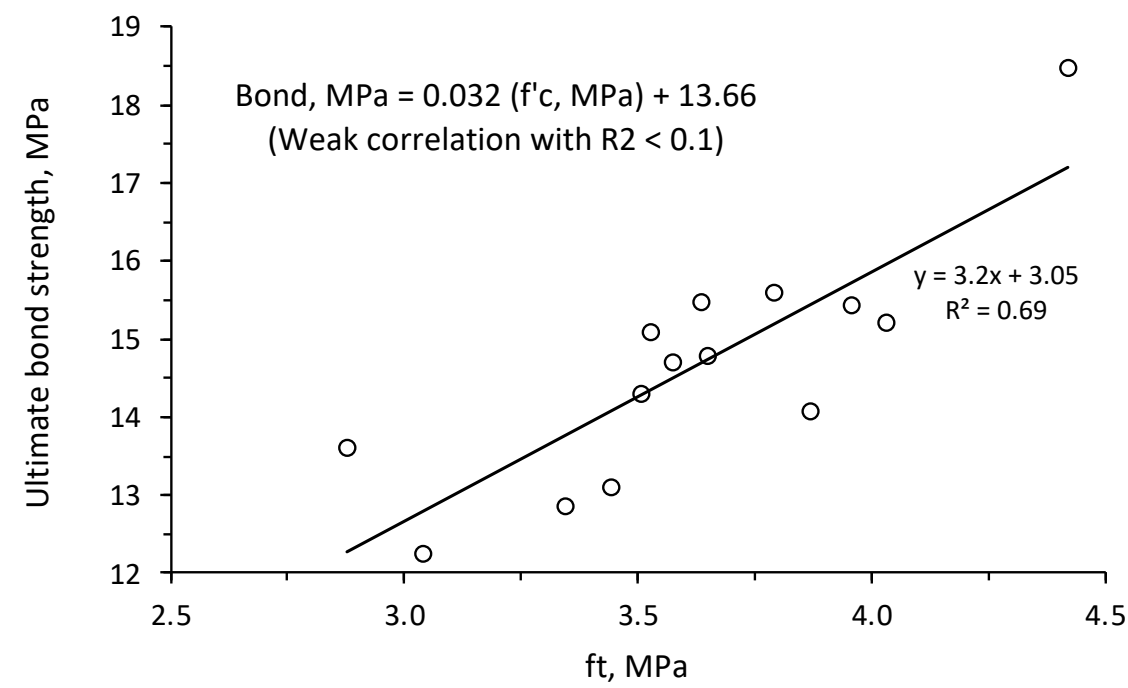

Figure 10. Relationship between bond strength and $\mathrm{ft}$ for all tested mixtures.

\subsubsection{Comparison with ACI 318-19 and CEB-FIP Bond Models}

The experimental $\tau_{\max }$ values determined following the RILEM/CEB/FIB recommendations are compared with the design ultimate bond strength $\left(\tau_{\mathrm{u}}\right)$ specified in ACI 318-19 [55] and CEB-FIP models [56]. The $\tau_{\mathrm{u}}$ proposed by ACI 318-19 is expressed as:

$$
\tau_{\mathrm{u}}=\frac{10 \sqrt{\mathrm{f}_{\mathrm{c}}^{\prime}}\left(\frac{\mathrm{C}_{\mathrm{b}}+\mathrm{K}_{\mathrm{tr}}}{\mathrm{d}_{\mathrm{b}}}\right)}{4 \times 9 \Psi_{\mathrm{t}} \Psi_{\mathrm{e}} \Psi_{\mathrm{s}} \lambda}
$$

where $C_{b}$ and $K_{t r}$ refer to the concrete cover and transverse reinforcement index, respectively (i.e., the $\left(C_{b}+K_{t r}\right) / d_{b}$ ratio is limited to 2.5). The $\Psi_{e}, \Psi_{t}, \Psi_{s}$, and $\lambda$ factors refer to epoxy coated bars, bar location with respect to the upper surface, bar-size, and lightweight concrete, respectively. In this study, $\Psi_{\mathrm{S}}$ is taken as 0.8 for bars No. 10, while the other 
parameters taken are equal to 1 . The $\tau_{\mathrm{u}}$ expression proposed by CEB-FIP for confined concrete is given as:

$$
\tau_{\mathrm{u}}=2 \sqrt{\mathrm{f}_{\mathrm{c}}^{\prime}}
$$

Table 3 summarizes the $\tau_{\mathfrak{u}}$ values determined using the ACI 318-19 and CEB-FIP bond models as well as the experimental-to-design bond strength ratios (i.e., $\tau_{\max } / \tau_{\mathrm{u}}$ ). As can be seen, the $\tau_{\max } / \tau_{\mathrm{u}}$ values determined from ACI 318-19 model hovered about $3.1 \pm 0.6$, revealing the conservative nature of this equation to predict the bond strengths of PET-modified concrete. In contrast, the $\tau_{\mathrm{u}}$ values determined from the CEB-FIP model were slightly lower than $\tau_{\max }$, which resulted in $\tau_{\max } / \tau_{\mathfrak{u}}$ values varying from 1.18 to 1.52 .

\section{Conclusions}

Based on the foregoing, the following conclusions can be warranted:

1. The concrete mechanical properties were curtailed with PET additions, given their lightweight nature and poor characteristic strength compared to aggregate particles. The threshold PET rate was equal to $4.5 \%$, by concrete volume.

2. The $\mathrm{w} / \mathrm{c}$ reduction proved efficient to compensate for the drop in strength due to PET additions, as well as to reduce the concrete proneness towards sorptivity and drying shrinkage. However, the increased HRWR demand necessary to adjust workability detrimentally altered concrete stability and resistance to bleeding.

3. The tensile-related properties were fully recovered by the incorporation of SF and SBR. The former phenomenon was attributed to the fibers' bridging effect that delays the formation and propagation of cracks, while the latter was associated with the presence of polymeric films that coalesce and strengthen the cement-aggregate and cement-PET interfacial transition zones.

4. For a given PET rate, the mechanical properties of RCA concrete were inferior to equivalent NCA mixtures, due to lower aggregate density and weaker properties. The resulting threshold PET rate was equal to $3 \%$, by concrete volume, given the coupled detrimental effects of RCA and waste plastics on strength development.

5. The three distinct regions commonly observed in the bond stress vs. slip curves for unmodified concrete were not altered by PET additions. Concurrent with the mechanical properties, the bond strength dramatically degraded at $4.5 \%$ and $3 \%$ rates in NCA and RCA concrete, respectively.

6. The concrete modification either by reducing $\mathrm{w} / \mathrm{c}$ or incorporating SF or SBR was efficient to restore the bond properties for NCA and RCA concrete. Although different modes of action, however, the three approaches are beneficial to strengthen the adhesive and mechanical components of bonds in the vicinity of steel bars.

7. An acceptable correlation exists between the splitting tensile concrete strength and bond to steel bars, for both NCA and RCA mixtures.

Author Contributions: Conceptualization, J.J.A. and J.M.K.; methodology, J.J.A. and J.M.K.; software, R.G.; validation, J.J.A. and J.M.K.; formal analysis, J.J.A., J.M.K. and R.G.; investigation, J.J.A. and R.G.; resources, J.J.A.; data curation, J.J.A. and R.G.; writing-original draft preparation, J.J.A. and R.G.; writing-review and editing, J.J.A. and J.M.K.; visualization, J.J.A. and J.M.K.; supervision, J.J.A.; project administration, J.J.A. All authors have read and agreed to the published version of the manuscript.

Funding: This research received no external funding.

Institutional Review Board Statement: Not applicable.

Informed Consent Statement: Not applicable.

Conflicts of Interest: The authors declare that there is no conflict of interest regarding the publication of this paper. 


\section{References}

1. The World Bank Home Page. Available online: https://datatopics.worldbank.org/what-a-waste/index.html (accessed on 2 February 2021).

2. United Nation. COP26: The Negotiations Explained. In Proceedings of the 26th UN Climate Change Conference UK, Glasgow, UK, 31 October-13 November 2021.

3. Siddique, R.; Khatib, J.; Kaur, I. Use of recycled plastic in concrete: A review. Waste Manag. 2008, 28, 1835-1852. [CrossRef]

4. Singh, N.; Hui, D.; Singh, R.; Ahuja, I.P.S.; Feo, L.; Fraternali, F. Recycling of plastic solid waste: A state of art review and future applications. Compos. Part B Eng. 2017, 115, 409-422. [CrossRef]

5. Khatib, J.; Jahami, A.; Elkordi, A.; Abdelgader, H.; Sonebi, M. Structural Assessment of Reinforced Concrete Beams Incorporating Waste Plastic Straws. Environments 2020, 7, 96. [CrossRef]

6. Choi, Y.W.; Moon, D.J.; Kim, Y.J.; Lachemi, M. Characteristics of mortar and concrete containing fine aggregate manufactured from recycled waste polyethylene terephthalate bottles. Constr. Build. Mater. 2009, 23, 2829-2835. [CrossRef]

7. Hannawi, K.; Kamali-Bernard, S.; Prince, W. Physical and mechanical properties of mortars containing PET and PC waste aggregates. Waste Manag. 2010, 30, 2312-2320. [CrossRef]

8. Khatib, J.M.; Jefimiuk, A.; Khatib, S. Flexural behaviour of reinforced concrete beams containing expanded glass as light-weight aggregates. Slovak J. Civ. Eng. 2015, 23, 1-7. [CrossRef]

9. Saxena, R.; Siddique, S.; Gupta, T.; Sharma, R.K.; Chaudhary, S. Impact resistance and energy absorption capacity of concrete containing plastic waste. Constr. Build. Mater. 2018, 176, 415-421. [CrossRef]

10. Liu, T.; Nafees, A.; Khan, S.; Javed, M.F.; Aslam, F.; Alabduljabbar, H.; Xiong, J.-J.; Khan, M.I.; Malik, M. Comparative study of mechanical properties between irradiated and regular plastic waste as a replacement of cement and fine aggregate for manufacturing of green concrete. Ain Shams Eng. J. 2021, 13, 101563. [CrossRef]

11. Saikia, N.; de Brito, J. Mechanical properties and abrasion behaviour of concrete containing shredded PET bottle waste as a partial substitution of natural aggregate. Constr. Build. Mater. 2014, 52, 236-244. [CrossRef]

12. Belmokaddem, M.; Mahi, A.; Senhadji, Y.; Pekmezci, B.Y. Mechanical and physical properties and morphology of concrete containing plastic waste as aggregate. Constr. Build. Mater. 2020, 257, 119559. [CrossRef]

13. Basha, S.I.; Ali, M.R.; Al-Dulaijan, S.U.; Maslehuddin, M. Mechanical and thermal properties of lightweight recycled plastic aggregate concrete. J. Build. Eng. 2020, 32, 101710. [CrossRef]

14. Ferreira, L.; de Brito, J.; Saikia, N. Influence of curing conditions on the mechanical performance of concrete containing recycled plastic aggregate. Constr. Build. Mater. 2012, 36, 196-204. [CrossRef]

15. Adamu, M.; Trabanpruek, P.; Jongvivatsakul, P.; Likitlersuang, S.; Iwanami, M. Mechanical performance and optimization of high-volume fly ash concrete containing plastic wastes and graphene nanoplatelets using response surface methodology. Constr. Build. Mater. 2021, 308, 125085. [CrossRef]

16. Talamona, D.; Tan, K.H. Properties of recycled aggregate concrete for sustainable urban built environment. J. Sustain. Cem. Mater. 2012, 1, 202-210. [CrossRef]

17. Alzard, M.H.; El-Hassan, H.; El-Maaddawy, T. Environmental and Economic Life Cycle Assessment of Recycled Aggregates Concrete in the United Arab Emirates. Sustainability 2021, 13, 10348. [CrossRef]

18. Butler, L.J.; West, J.S.; Tighe, S.L. Towards the classification of recycled concrete aggregates: Influence of fundamental aggregate properties on recycled concrete performance. J. Sustain. Cem. Mater. 2014, 3, 140-163. [CrossRef]

19. Assaad, J.J.; Matar, P.; Gergess, A. Effect of quality of recycled aggregates on bond strength between concrete and embedded steel reinforcement. J. Sustain. Cem. Mater. 2019, 9, 94-111. [CrossRef]

20. Xie, T.-Y.; Zhao, X.-Y. Can a local bond test truly reflect impact of recycled aggregate on the bond between deformed steel bars and recycled aggregate concrete?-A critical assessment and development of a generic model. Eng. Struct. 2021, $244,112826$. [CrossRef]

21. Su, T.; Wang, T.; Wang, C.; Yi, H. The influence of salt-frost cycles on the bond behavior distribution between rebar and recycled coarse aggregate concrete. J. Build. Eng. 2021, 45, 103568. [CrossRef]

22. Godat, A.; Aldaweela, S.; Aljaberi, H.; Al Tamimi, N.; Alghafri, E. Bond strength of FRP bars in recycled-aggregate concrete Constr. Build. Mater. 2020, 267, 120919. [CrossRef]

23. Wang, W.; Wang, Y.; Li, D.; Liu, Y.; Li, Z. Bond-slip behavior between basalt fiber reinforced plastic bars and recycled aggregate concrete. Constr. Build. Mater. 2021, 302, 124360. [CrossRef]

24. Kachouh, N.; El-Hassan, H.; El-Maaddawy, T. Influence of steel fibers on the flexural performance of concrete incorporating recycled concrete aggregates and dune sand. J. Sustain. Cem. Mater. 2020, 10, 165-192. [CrossRef]

25. Ohama, Y. Handbook of Polymer-Modified Concrete and Mortars: Properties and Process Technology; Noyes Publications: Saddle River, NJ, USA, 1995.

26. Assaad, J.J.; Daou, A.; Daou, Y. Bond Properties of Polymer-Modified Lightweight Self-Consolidating Concrete Containing Expanded Polystyrene. Adv. Civ. Eng. Mater. 2019, 8, 558-572. [CrossRef]

27. Miranda, M.P.; Morsch, I.B.; Brisotto, D.D.S.; Bittencourt, E.; Carvalho, E.P. Steel-concrete bond behavior: An experimental and numerical study. Constr. Build. Mater. 2020, 271, 121918. [CrossRef]

28. Watts, M.J.; Amin, A.; Bernard, E.S.; Gilbert, R.I.; Facconi, L. Early age bond stress-slip behaviour of macro-synthetic fibre reinforced concrete. Constr. Build. Mater. 2021, 301, 124097. [CrossRef] 
29. Raad, D.; Assaad, J.J. Structural properties of fiber-reinforced concrete containing thermosetting polymer plastic wastes. J. Sustain. Cem. Mater. 2021, 1-16. [CrossRef]

30. Assaad, J.; Daou, Y. Behavior of structural polymer-modified concrete containing recycled aggregates. J. Adhes. Sci. Technol. 2016, 31, 874-896. [CrossRef]

31. Wang, Z.J.; Wang, R.; Bin Cheng, Y. Mechanical Properties and Microstructures of Cement Mortar Modified with StyreneButadiene Polymer Emulsion. Adv. Mater. Res. 2010, 168, 190-194. [CrossRef]

32. Mahdi, F.; Abbas, H.; Khan, A.A. Flexural, shear and bond strength of polymer concrete utilizing recycled resin obtained from post consumer PET bottles. Constr. Build. Mater. 2013, 44, 798-811. [CrossRef]

33. ASTM C496/C496 M; Standard Specification for Chemical Admixtures for Concrete; Annual Book of ASTM Standards. ASTM International: West Conshohocken, PA, USA, 2019.

34. ASTM C33/C33 M; Standard Specification for Concrete Aggregates; Annual Book of ASTM Standards. ASTM International: West Conshohocken, PA, USA, 2018.

35. ASTM C117; Standard Test Method for Materials Finer than 75-lm (No. 200) Sieve in Mineral Aggregates by Washing; Annual Book of ASTM Standards. ASTM International: West Conshohocken, PA, USA, 2017.

36. ASTM C128; Standard Test Method for Relative Density (Specific Gravity) and Absorption of Fine Aggregate; Annual Book of ASTM Standards. ASTM International: West Conshohocken, PA, USA, 2015.

37. ASTM A615/A615 M; Standard Specification for Deformed and Plain Carbon-Steel Bars for Concrete Reinforcement; Annual Book of ASTM Standards. ASTM International: West Conshohocken, PA, USA, 2020.

38. EFNARC. The European Guidelines for Self-Compacting Concrete. The European Guidelines for Self Compacting Concrete, (May). Available online: http:/ / www.efnarc.org/pdf/SCCGuidelinesMay2005.pdf (accessed on 15 April 2020).

39. ACI 548.3R-03 (2003); Polymer-Modified Concrete. American Concrete Institute: Farmington Hills, MI, USA, 2003; 40p.

40. Puthussery, J.V.; Kumar, R.; Garg, A. Evaluation of recycled concrete aggregates for their suitability in construction activities: An experimental study. Waste Manag. 2017, 60, 270-276. [CrossRef]

41. ASTM C143/C143M-15a; Standard Test Method for Slump of Hydraulic-Cement Concrete; Annual Book of ASTM Standards. ASTM International: West Conshohocken, PA, USA, 2015.

42. ASTM C231/C231M-17a; Standard Test Method for Air Content of Freshly Mixed Concrete by the Pressure Method; Annual Book of ASTM Standards. ASTM International: West Conshohocken, PA, USA, 2017.

43. ASTM C642; Standard Test Method for Density, Absorption, and Voids in Hardened Concrete; Annual Book of ASTM Standards. ASTM International: West Conshohocken, PA, USA, 2013.

44. ASTM C39/C39M; Standard Test Method for Compressive Strength of Cylindrical Concrete Specimens; Annual Book of ASTM Standards. ASTM International: Conshohocken, PA, USA, 2018.

45. ASTM C496/C496M; Standard Test Method for Splitting Tensile Strength of Cylindrical Concrete Specimens; Annual Book of ASTM Standards. ASTM International: Conshohocken, PA, USA, 2017.

46. ASTM C597; Standard Test Method for Pulse Velocity Through Concrete; Annual Book of ASTM Standards. ASTM International: Conshohocken, PA, USA, 2017.

47. ASTM C1585; Standard Test Method for Measurement of Rate of Absorption of Water by Hydraulic-Cement Concretes; Annual Book of ASTM Standards. ASTM International: West Conshohocken, PA, USA, 2013.

48. ASTM C157/C157M; Standard Test Method for Length Change of Hardened Hydraulic-Cement Mortar and Concrete; Annual Book of ASTM Standards. ASTM International: Conshohocken, PA, USA, 2017.

49. RILEM/CEB/FIB. Bond test for reinforcing steel: 2, pullout test. Mater. Struct. 1970, 3, 175-178.

50. MacGregor, J.G.; Wight, J.K. Reinforced Concrete: Mechanics and Design; Prentice Hall South Asia-Pearson Education: Singapore, 2018.

51. Zéhil, G.-P.; Assaad, J.J. Feasibility of concrete mixtures containing cross-linked polyethylene waste materials. Constr. Build. Mater. 2019, 226, 1-10. [CrossRef]

52. Jabbour, R.; Assaad, J.J.; Hamad, B. Cost-to-performance assessment of polyvinyl alcohol fibers in concrete structures. Mech. Adv. Mater. Struct. 2021. [CrossRef]

53. Machaka, M.; Elkordi, A.; Ghanem, H.; Khatib, J.; Baalbaki, O. Selected properties of concrete containing palm fibers. Acad. J. Civ. Eng. 2019, 37, 279-286. [CrossRef]

54. Jahami, A.; Khatib, J.; Baalbaki, O.; Sonebi, M. Prediction of deflection in reinforced concrete beams containing plastic waste Acad. J. Civ. Eng. 2019, 37, 551-555. [CrossRef]

55. ACI Committee 318. Building Code Requirements for Structural Concrete (ACI 318M-19) and Commentary (ACI 318RM-19); American Concrete Institute: Farmington Hills, MI, USA, 2019.

56. fib (International Federation for Structural Concrete). Model Code for Concrete Structures; Ernst \& Sohn: Berlin, Germany, 2013. 